\title{
Tigre celtique et roman " gothique » : Claire Kilroy, The Devil I know
}

\section{Claude Fierobe}

\section{Q OpenEdition \\ 1 Journals}

\section{Electronic version}

URL: http://journals.openedition.org/etudesirlandaises/4742

DOI: 10.4000/etudesirlandaises.4742

ISSN: 2259-8863

\section{Publisher}

Presses universitaires de Rennes

\section{Printed version}

Date of publication: 15 December 2015

Number of pages: 121-136

ISBN: 978-2-7535-4366-9

ISSN: 0183-973X

\section{Electronic reference}

Claude Fierobe, «Tigre celtique et roman « gothique » : Claire Kilroy, The Devil I know », Études irlandaises [Online], 40-2 | 2015, Online since 15 December 2017, connection on 04 May 2019. URL : http://journals.openedition.org/etudesirlandaises/4742 ; DOI : 10.4000/etudesirlandaises.4742 


\title{
Tigre celtique et roman " gothique " : Claire Kilroy, The Devil I Know
}

\author{
Claude Fiérobe \\ Université de Reims Champagne-Ardenne
}

Résumé

Le quatrième roman de Claire Kilroy, The Devil I Know, est un tableau cauchemardesque de l'Irlande dévastée par l'implosion de l'économie, rendue possible par la cupidité et la folie générales. En coulisse, c'est le démon qui tire les ficelles des marionnettes humaines. Tristram, qui est à la fois sa victime et son complice, ou son "interprète ", a sous les yeux les ruines de sa " grande maison " dans un projet immobilier monstrueux et, plus généralement, "les vestiges d'une civilisation morte ". The Devil I Know est une sombre fable morale à laquelle le " gothique ", adroitement actualisé, fournit les ressources narratives nécessaires.

Mots clés : littérature irlandaise, roman gothique, fable morale, Tigre celtique, promoteur immobilier, corruption, cupidité, inquiétante étrangeté, démon, damnation.

\section{Abstract}

Claire Kilroy's fourth novel, The Devil I Know, is a nightmarish picture of Ireland devastated by the implosion of the economy and by the greed and folly of all. Behind the scenes, the devil himself pulls the strings of the human puppets. Tristram, who is both his victim and his accomplice, his "interpreter", witnesses the ruin of his own "big house" in a monstrous property development, and more generally "the remnants of a dead civilisation". The Devil I Know is a dark moral fable to which the "gothic", cleverly updated, furnishes all the necessary narrative resources.

Keywords: Irish literature, gothic novel, moral fable, Celtic Tiger, property developer, corruption, greed, uncanny, devil, damnation.

Un tableau - Girl in the Mirror - dans All Summer (2003), un violon dans Tenderwire (2006), peinture et musique donc, deux façons proches l'une de l'autre de sonder le mystère de l'identité, singulièrement de l'identité féminine, tout en évoquant les profondeurs troublantes de la mémoire incertaine. En 2009, dans All Names Have Been Changed, Claire Kilroy aborde un autre domaine, celui de la création littéraire, en donnant la parole à un narrateur masculin, Declan étudiant en "creative writing " à Trinity College. Comme All Summer, The Devil I Know (2012) est une longue confession. D'un genre particulier, elle prend la forme du témoignage de Tristram Saint Laurence, durant ses dix jours de compa- 
rution devant un tribunal de Dublin. Double écho de Sterne: d'abord le nom du héros bien sûr, et ensuite le rythme de la composition du livre où figurent, comme dans Tristram Shandy, des chapitres très brefs, réduits parfois à une seule phrase, voire un seul mot ("The Viking ", 279). The Devil I Know, roman de Dublin - il y en a beaucoup de Joyce à Neil Jordan ou Sean O'Reilly - est une évocation pleine de bruit et de fureur des méfaits du Tigre celtique, animal un temps domestiqué, retourné à l'état sauvage. Si l'économie est devenue folle, elle n'est que la face visible d'une terrible réalité, d'un désastre qui concerne à la fois le sort des hommes sur cette terre et le salut de leur âme dans l'au-delà. Une épigraphe empruntée au début de Finnegans Wake nous entraine vers Howth Castle, modèle de Hilltop, propriété que Tristram tient de sa mère.

\section{A Glimpse of Paradise}

Au commencement le paradis. ${ }^{1}$ Il est là, à portée de la main. Un paysage à couper le souffle :

The truck ascended past ponied meadows and heathered slopes until the road crested and Dublin Bay appeared below, broad and smooth and greyish blue, patrolled by the Baily lighthouse. The whitethorn was in full blossom and the ferns were pushing through. (16)

Aucun doute sur ce qui s'offre aux yeux de Tristram le narrateur et de son ami - ami, vraiment? - Hickey le promoteur : l'Irlande dans toute la beauté d'une nature intacte. Mais voilà, l'enchantement est balayé par quelques phrases rageuses :

Better to have been born somewhere dismal, I sometimes think. Better to have grown up shielded from striking natural beauty, to have never caught that glimpse of Paradise in the first place only to find yourself sentenced to spending the rest of your life pining for it. (16)

On ne saurait être plus clair : le paradis est perdu et il n'a pas été retrouvé. Ce qui nous attend est bien le récit d'une condamnation ("sentenced»), un récit placé sous l'égide de la morale. Car une faute a été commise, dont un aperçu nous est donné dans la même page :

Hickey loaded me into his labourer's truck along with the rest of the junk he'd accumulated - Coke cans and crisp packets, chocolate wrappers and Lotto tickets, rolled up Daily Stars. (15)

1. Édition utilisée : Claire Kilroy, The Devil I Know, London, Faber and Faber, 2012. 
Tristram découvre le paysage depuis ce pick-up crasseux où Hickey passe une bonne partie de son temps. Concentré d'une modernité pervertie, l'univers de Hickey est celui de la consommation, du jeu, des media, et des déchets : " He cleared the passenger seat of debris with a swipe of the hand. " (15) Un univers contre nature : "I rolled the window up to seal the beauty out." (16) Tristram se cramponne à une lueur d'espoir, mais ce n'est qu'une illusion fugace - " for a moment " - : "The sun and sea, the harbour and the islands, the horses and the gorses [...] Not a precious thing had changed." (17) Pour dire vrai, tout a déjà changé et tout va encore changer. Demeure l'apparence d'une plaisante ruralité :

Windgate road still retained the leafy air of a country lane [...] Verges of cow parsley, honeysuckle, buttercups [...] The bluebells were still in blossom, thousands of them lining the forest floor. (42)

Mais tout n'est que leurre, le mal est déjà fait : «A country lane punctuated by ten-foot high electronic security gates [...] " (42) Ce mal va s'étendre, le promoteur a estimé d'un coup d'oeil le nombre de constructions possibles, et la nature ne représente que la plus-value qu'elle apporte : "Retain the mature trees, obviously, or a few of them at least. Mature trees sold a development. " (42)

Alors s'établit nettement au-dessus de la baie de Dublin une frontière entre deux domaines distincts, celui du paysage originel et celui d'une urbanisation caricaturale à l'image des nouvelles résidences des parvenus et de leurs palmiers, à l'image donc du « ranch » de Hickey:

Hickey had built a mock-colonial ranch on the side of the East Mountain. A row of floodlit palm trees delineated the end of nature's dominion over the moors and the beginning of the reign of the developer. (211)

Monde nouveau où le faucon crécerelle ne songe pas à s'aventurer, se contentant de voler "beyond Hickey's boundary. " (216) Reste qu'en compagnie d'Edel, la femme de Hickey qui deviendra sa maitresse, Tristram a encore tout loisir de contempler la mer argentée à peine ridée par une brise légère : "It looks as if you could walk on it", Edel said." (218) Mais le temps des miracles est bien passé et le pire est à venir. Il est annoncé malicieusement, dans ce texte qui ne manque jamais de causticité, par une présence insolite a priori, celle d'une pomme qui roule dans le tableau de bord du pick-up. La pomme, symbole de la chute : elle dégringole en effet, et Tristram la dépose dans l'emplacement du frein à main.

Elle annonce sur le mode mineur ce qui est sans doute la scène la plus terrible de tout le livre : le barbecue. En majeur, cette fois-ci, le martyre de la nature. Hickey a invité Tristram, et bien sûr les membres du Cercle d'Or et autres nouveaux riches, tous arrivés en hélicoptères ou en limousines noires - "Money kills the imagination" (212). Le barbecue donc, morceau de bravoure littéraire, véri- 
table exemplum, métaphore terrifiante de la folie qui a saisi l'Irlande du boom économique. Hickey est fier d'apporter les homards, heureux de parader : " $I$ caught these lads meself this morning [...] Fresh from Balscadden bay. Thought we'd give them a lash on the barbie! » (214) Son fils a déjà essayé de crever l'œil d'un des crustacés, Hickey va les jeter vivants sur le grill. Pays saccagé, animaux torturés. S'ils s'échappent, le Viking, autre profiteur du système, les écrase d'un coup de talon avant de les remettre à cuire : "Their various pairs of legs extended and retracted until they finally expired. " (215) Après la mise à mort, la dévoration, c'est Hunger qui se précipite pour être le premier, Hunger ainsi nommé pour avoir fait fortune en s'appropriant les affaires les plus juteuses venues devant les tribunaux depuis les années 1990, Hunger qui mange à tous les rateliers : "Don't tell me you didn't know he was working for the other team too? " (215) L'antenne du crustacé bouge encore? Hunger la fourre dans sa bouche : "It's dead now. » (216) La digestion sera plus difficile. Le homard est démembré alors qu'il n'est pas encore mort, comme est démembrée l'Irlande livrée à l'appétit insatiable des spéculateurs. Comme est troué, percé, éviscéré, un territoire vivant, sorte de prélude à une exécution définitive que la crise a au moins le mérite d'annuler, à moins qu'un accès de fièvre ne surgisse à nouveau. Repas de sauvages, retour à la barbarie.

Une campagne violée, à l'image des animaux en proie à l'avidité des rapaces humains, autoproclamés Cercle d'Or. Ce thème animal, Claire Kilroy n'est pas la seule à s'en emparer. Avant elle Dermot Bolger (Night Shift), John McGahern ("Creatures of the Earth»), Keith Ridgeway (Animals), avaient, chacun à sa façon, stigmatisé l'inconduite des hommes à l'égard des bêtes. Mais il n'y a pas que la cruauté évidente, il y a la négligence coupable qui prépare sournoisement la catastrophe, ou plutôt qui en est le signe annonciateur. Ainsi se trouvent mis en parallèle deux abandons, l'un renvoyant à l'autre par un procédé d'osmose douce qui contraste singulièrement avec la cruauté de la scène du barbecue. Le passage imprévu de Tristram à Dublin se transforme en un séjour qui est lui-même un retour aux origines. Hickey le tentateur est à l'œuvre : "I hoped he wasn't bringing me where I thought he was. And then he did. " (42) Le voici, ce lieu redouté : "Hickey pulled in at the old stone gate pillars. The name of the house was barely legible. "Hilltop" it read beneath the clusters of lichen. "(42) Hilltop, objet des convoitises du promoteur. Ainsi se noue un faisceau sémantique fort et ordonné, né d'une conjonction de plusieurs éléments du roman : l'alcoolisme de Tristram, son origine sociale, l'abandon de la propriété et celui du poney. L'innocence de l'enfance est perdue.

Nous voici en terrain familier. Tristram St Lawrence est le descendant d'une grande famille anglo-normande et Hilltop, la "big house " où s'est déroulée son enfance heureuse. Il est cet Absentee de la tradition qui revient au pays, visite le domaine qu’il a délaissé avant de le livrer au délire spéculatif. Structure roma- 
nesque récurrente depuis le XIX ${ }^{\mathrm{e}}$ siècle, quasi-cliché : Claire Kilroy utilise et actualise un schéma connu. Elle insiste : "Like the gate, it [the front door] was sagging on its hinges, as if the departure of the family home had caused Hilltop to slump in dejection. " (43) Le parc n'a jamais été entretenu, il est envahi par une végétation folle - "The rhododendrons bushes had bolted the size of caravans, and what had once been the lower lawn was now a drift of ferns" (46) - le bois des barrières est vermoulu, la peinture est écaillée. Et puis il y a Prince, le poney, le compagnon adoré des jeux de jadis, abandonné à son sort depuis des années, apparition irréelle, comme un reproche vivant, si peu vivant, jeté à la face du promoteur, indifférent - "It's only a moth-eaten oul pony ", - et du proprétaire ému jusqu'aux larmes - "A tear was rolling down my cheek" (50) - : "His back was a knuckled ridge of spine and his hips propped up his hindquarters like tent poles. " (49) La mort est au rendez-vous : "Animals must know when they are finished. They may not undestand death, as such, only that the world had left them behind, that it is time to lie down. " (50) Comble d'ironie, c'est "le méchant homme " (" the bad man ", 50) qui offre au pauvre animal la pomme du tableau de bord, symbole équivoque où se mêlent compassion et châtiment. Prince sera mis à mort (on dit euthanasié, n'est-ce pas?) expulsé du jardin d'Eden, "Life was simpler then " (46) sans avoir compris de quoi on l'accusait : "I fear that every blessed thing on this earth is cursed with the capacity to wander at its predicament-Prince was left wondering what he'd done wrong. " (49)

Prémonitoire, un coup de tonnerre clôt cette évocation d'un paradis perdu : "A dry crack of thunder warped the air followed by a second flash of ligtning. " (51) Attention : ce qui est dit des animaux vaut pour les hommes qui grouillent dans l'immense excavation du chantier :

At the bottom of the pit was a whole civilisation. Machinery, lights, materials, tools. And men. There were a rake of them down there. Miniature men grubbing about in the dirt like the creatures exposed when you lifted a rock. (163)

Écho à peine voilé de la visite du parc à l'abandon : "I lifted one of the showjumping poles and panicked woodlice scurried down its length. The grass underneath was moulded into a curd-white channel speckled with slugs. » (46)

\section{图 I want to make a big splash}

Certes Tristram pleure sur ses terres désolées et sur le poney moribond. Malheureusement, il n'en reste pas là. Par sa passivité - il se laisse instrumentaliser par Deauville qui en fait une sorte d'homme de paille à demi consentant, privé de réelle lucidité, il se laisse emporter par Hickey, littéralement, dans sa voiture, 
vers sa perte - il s'abandonne au délire spéculatif qui s’est emparé des milieux d'affaires. Les Irlandais s'aveuglent à la beauté de l'Irlande, se retournent vers celle qui les a nourris pour la dévorer, inversant la célèbre formule de Joyce : "Ireland is the old sow that eats her farrow» ${ }^{2} \mathrm{Il}$ y a bien pour Tristram un retour aux origines : "I consulted my watch and it said that the time was early summer and that I was a boy of eighteen again, no damage done. " (18) Pure illusion cependant, car le chaos menace. Chaos intérieur d'abord qui mène son assaut sur le point faible de Tristram : l'alcoolisme qu'il a tenté de fuir d'un continent à l'autre, d'un hémisphère à l'autre. Torturé par le manque, Tristram n'évite la récidive que par un appel du mystérieux Deauville qui envoie un taxi le soustraire à la tentation en l'emportant vers une réunion des Alcooliques Anonymes. Hickey l'avait entrainé vers The Summit, le pub fréquenté jadis, où s'ouvrent les portes d'un enfer à l'odeur irrésistible, celle de la bière brune, invitation pressante, quasi irrésistible, à sombrer dans « un puits d'obscurité »:

We waited for the tumult within the glasses to settle, the chaos that miraculously resolves itself into a well of black topped by a head of cream - a trick, a cruel trick - it never resolves, but lapses back into chaos the second you swallow it. A chaos so calamitous that you don't know where to turn to escape it, but by then it is too late. The chaos is inside you. That is the nature of a pint. (21)

À la menace toujours présente mais encore virtuelle de ce chaos intérieur correspond la réalité terrifiante de l'incroyable dérèglement qui a submergé l'Irlande. Mépris des règles dont l'artisan en est le bien nommé ministre Ray Lawless, "A rain-coloured man with rain-coloured hair and rain-tinted glasses on his nose." (109) Sans foi ni loi, il est d'une cupidité sans limite, et surtout ne vous méprenez pas sur le sens de son prénom:

He was not ray as in a sunbeam, but ray as in the fish, that ugly fish with its mournful face the colour of a mushroom. Ray the bottom feeder. Steadily making its way along the ocean bed, ingesting the tiny creatures that strayed across its path, never hungry, never full [...]. (113)

Autre prédateur, Hickey, celui qui répète à l'envi : " I want to make a big splash" (181). Le saccage peut commencer. En mode mineur d'abord. Son pick-up dévale à travers le parc: "The truck slewed sideways across the sodden lawn, spraying mud like a slurry spreader [...] What had been a meadow of butterflies and wildflowers was now a ploughed field." (54)

2. James Joyce, A Portrait of the Artist as a Young Man, (1916), London, Granada, 1977, p. 185. 
Hickey est homme de terrain, ne dit-on pas qu'il est "physically adapted to the muck»? Certes, mais pas seulement. Il est homme et bête à la fois, et son hybridité en fait une créature redoutable dans la société contemporaine :

[...] so he was not a man but something hybrid, something wolfish, something that wore its pelt on the inside ${ }^{3}$, because they were a new breed, weren't they, these developers. (188)

L'animalité du personnage est soulignée à maintes reprises. Il est un chien : "Hickey drove as a dog might, with some part of his anatomy - his elbow or sometimes his head-shoved out the window" (41); un loup : "He flashed me a wolfish smile" (41) ; un taureau : "He went at everything in that manner : bullishly [...]" (44); une bête féroce : "Hickey bared his teeth at me, the enamel gleaming through his black beard like bone exposed in a wound. " (213) Tel une divinité nouvelle il trône au milieu de son chantier " a god admiring his handiwork from the heavens, picking out which bit he might like to toy with nex". (119) En effet, il peut tout saisir dans sa main. Sa tête est pleine de "plastic models " qui caractérisent sa relation au monde : "He had reduced it in scale to a size that was manageable, malleable, an entity he could carve and sell. " (119)

Voilà l'homme, si peu humain, qui sert le noir dessein de Deauville, soumettre entièrement l'Irlande à l'appât du gain, la contraindre à perdre sa raison et son âme : "Money disrupts the cognitive process. It guns electrodes to your skull and scrambles your brains. " (72) La fièvre qui saisit Tristram et Hickey n'est que l'image d'un délire collectif, œuvre du démon qui se retirera, si on peut dire, affaire faite. Collectif oui, les personnages ayant perdu leur identité et, comme dans les romans de Dickens ${ }^{4}$, étant devenus interchangeables: "They were all the same. Boyler, Coyler, Doyler, sitting there, sharpening their knives. " (231)

Claire Kilroy force le trait jusqu'à la caricature, preuve de sa réaction d'horreur en face d'un désastre dont elle multiplie les signes prémonitoires au premier rang desquels figure la " mort " de Tristram dans un hôpital de Bruxelles (somnifères et alcool) : "The registrar informed me that my heart had stopped beating. " (82) Comme Tristram, l'Irlande meurt : comme lui ne reviendra-t-elle d'entre les morts que pour mieux perdre son âme?

À la protestation navrée de Tristram - "You've destroyed my lawn » - la réponse de Hickey donne le ton : "I'l get you a new one" [...] "I am about to make you a rich man." " (55) Après, il lance ses machines à l'assaut du domaine et bien vite un cratère se creuse "as if a meteorite had struck." (163) Pour Hickey, c'est un

3. Écho de l'épisode du lycanthrope dans The Albigenses de C.R. Maturin : "I am a mad wolf. The hairs grow inward - the wolfish coat is within. ", The Albigenses, Hurst and Robinson, London, 1824, vol. I, p. 226.

4. Un exemple : "Mr Aggs, Mr Baggs, Mr Caggs, Mr Daggs, Mr Faggs, Mr Gaggs ", Charles Dickens, Our Mutual Friend, (1865), Penguin, 1974, p. 131. 
trou aux dimensions de son ambition, mais Tristram a conservé sa lucidité dans la fièvre générale - "Everybody sees different things when looking into an abyss. I see more than most " (164) - et s'il répugne à se confier c'est en raison de sa marginalité, de son incapacité à se joindre à l'euphorie dominante, quasiment érigée en règle de vie par le Taoiseach lui-même :

How could I have confessed my gut feeling to M. Deauville? That Hickey was digging us into a big hole. That across the country people were digging themselves into big holes, that big holes were spreading across Ireland like the pox, eating away at the heart of the island. (164)

La spéculation est une gigantesque arnaque, et l'Irlande est un pays de nondroit. Il n'y a plus d'autorité, il suffit de connaître le type qu'il faut (" the very man ", 122). L'état est à l'image monstrueuse du ministre rendu difforme par la cupidité : "And he was misshapen because he grabbed and grabbed, a country spilling over its borders, annexing smaller states, distending with each acquisition. " (112); il n' y a plus de fisc, Hickey assène la leçon : "'This isn't Elizabethan England, or wherever you're from. This is Ireland. The Tax Man's just a big joke here.' " (167) ; la loi n'est plus qu'un souvenir : " [...] the Building Control Act of 1990. The Building No Control Act, more like. It's all self-certification now - you're basically correcting your own exams. " (184) Il n'y a pas non plus d'argent, mais des obligations, des traites, du papier. Le boom économique de l'Irlande? Du vent. Bon exemple de ce que Julien Gracq appelle "l'émission continue de fausse monnaie 5 ". D'où l'image du vide, d'un creux d'où surgissent d'énormes sommes d'argent pour les profiteurs :

Castle Holdings was a shell company. I bought nothing, sold nothing, manufactured nothing, did nothing; and yet [...] it returned a profit of $£ 66$ million that first year [...] Who better to direct a shell company than a shell human being? (72-73)

Une série de cercles concentriques se dessine à la surface de notre monde l'Enfer de La Divine Comédie en est visiblement la matrice - cercles toujours plus larges où s'évanouit la notion même de réalité, à partir du "Cercle d'Or " initial : Hilltop, l'Irlande, l'Angleterre, Dubaï, Shangai, Pudong. Ses membres ont un surnom - " the Bills" pour "Billionaires" - qui définit bien leur seule raison d'être : "Their moniker betrayed the terrible hunger in them, the insatiable drive to acquire. " (138) Le sénateur McGee salue à sa façon l'audace de Tristram et Hickey - "Balls, these guys have balls, and balls are what we need." (140) Il n'a

5. Julien Gracq, Les Terres du Couchant, Paris, Corti, 2014, p. 22. 
pas tort puisque Hickey n’a jamais abandonné " le détecteur à métaux » de sa jeunesse (métaphore pertinente du sens des affaires), et il a fini par trouver un trésor :

I knew there was a treasure buried around here somewhere. I could smell it, so I could. And now I have found it. It was right under me nose all the time. Land. Or what happens to land when a man changes it into property.

L'alchimiste a réussi son grand œuvre : "I've transformed a heap of muck into gold." (142) Mais en peu de mois la crise dissipe ce qui n'était qu'une illusion, Deauville ne laisse planer aucune équivoque : "It's over, Tristram. The money is gone! » (294). À l'intention de Hickey - qui lui demande : "What money? " - Tristram se montre encore plus explicite : "All of it. All the money. My money, your money, McGee's money, Castle Holdingsimoney. The country's money. " (295) Deauville, "senior bondholder", sera le seul à ne rien perdre : "He says it means he is immune. He says it means we take the hit. " (295) Tristram met les points sur les i :

Deauville says the markets are in collapse. He says the world economy has begun to implode and that our assets have junk status. He says no one is going to want to buy them. And we paid for them with borrowed money. We paid for them with credit. Which in fact means debt. We owe more money than we can possibly count. (295-296)

Le texte maintient sa cohérence et se replie sur lui-même : le chaos extérieur engendre ici le chaos intérieur - c'était l'inverse au début du livre - celui qu'apporte l'alcool par le goulot de la bouteille de whiskey porté par Hickey à bouche de Tristram. Si le whiskey plonge à nouveau Tristram dans les entrailles de l'enfer, c'est le vin noir, le Brunello di Montalcino, qui connote la dépravation des membres du Cercle d'Or : "The wine was rich in tannin and it blackened their lips. I could smell it on their blackend breaths, their blackened hearts, their blackened souls." (237) Une formule frappante résume tout : "Building site to bomb site overnight. » (312) Elle s'applique à l'Irlande comme à Hilltop :

We were witnessing the remnants of a dead civilisation, one that had left nothing but wreckage in its wake, the Vandals or the Goths. Except that it had not been civilised at all. Civilisation was the wrong word. (312)

Retour à la sauvagerie donc, puisque prédation, dévoration et rapacité sont les moteurs de l'action, ceci au prix d'un divorce total d'avec la réalité, et de l'adhésion déraisonnée au mirage du progrès, en un acte de foi imbécile, "wishful thinking " propre à engendrer une catastrophe : "[...] lately in this country, wanting something to be true made it true. Wanting something to be worth a hundred million made it worth a hundred million. " (248-249) 


\section{Uncanny}

Il y a plus. La perpective réaliste qui semble gouverner le texte, déjà minée par la fusion de l'animal et de l'humain, se trouve profondément déstabilisée par la répétition lancinante de trois termes : uncanny, hell, tocka tocka. Ce n'est ni un hasard, ni une négligence.

Uncanny. Celui qui parle, se confesse, "témoigne " (le récit se divise en dix " days of evidence ") est cultivé, et surtout traducteur distingué, véritable prodige : "I do all the major European languages [...] I was recognised as the best at what I do. " (5-6) Vient très vite la première occurrence du terme uncanny et, pour enfoncer le clou, sa traduction en français et en allemand : "They said my gift was uncanny. That was the word my clients used in their various mother tongues. Etrange, unheimlich, uncanny. » (6) Unheimlich, Freud bien sûr, au cas où le lecteur n'aurait pas été assez attentif. Maître des mots, interprète et rien d'autre - "I am an interpreter, a perfect conduit, an instrument of others" (93) - mais ce n'est déjà pas si mal, Tristram affiche aux tournants majeurs de son existence le même marqueur de "l'inquiétante étrangeté ${ }^{\prime}$ ", en règle générale assorti de la formule " that was the word they used", avec quelque variantes. Un exemple vient d'être cité, il y en a de nombreux autres. Tristram est le directeur fantoche d'une compagnie fantoche, qu'à cela ne tienne : "M. Deauville could not have chosen a more fitting candidate. Uncanny. That was the word they used." (73) Tristram est cliniquement mort, mais revient à la vie, du jamais vu : "They had never seen anything like it before, the registrar said. Uncanny. That was the word they used." (82) Tristram est à la fois, avec la même facilité, un passeur de langages et un passeur d'argent : "Money travelled through me as freely as languages. Uncanny. That was the word they used. " (231) Uncanny est à la fois leitmotiv et programme : dans toute cette histoire, il y a quelque chose qui s'écarte de la norme, qui creuse l'abîme d'une folie contagieuse où les repères habituels ont été perdus de vue.

Or, c'est bien le narrateur qui consomme la métamorphose d'un ancien Eden en un univers anxiogène empli de créatures de cauchemar : "Graveyard ivy clotted the orchard walls in grotesque guises - cut-throats, hanged corpses, ghouls. I am a troubled man. I have a troubled mind. I see things in the dark. " (30) Tristram engendre l'Unheimlich, d'où l'obscurité d'un témoignage qui, à chaque nouveau jour de comparution, paraît prendre davantage ses distances avec le réel. À tel point que, pour ses juges comme pour lui-même, Tristram est insaisissable. Il ne sera pas saisi car il va partir très loin, là où, sans doute, personne ne pourra le suivre. De plus, il est une anomalie métaphysique, son existence participant de domaines a priori incompatibles. Il est d'abord, comme Lazare, revenu d'entre les morts, mais

6. Titre français adopté pour la traduction de l'essai de Freud, Das Unheimliche, publié en 1919. 
pour se sentir damné à tout jamais, "for there is no rest for the wicked. " (83) Il a échappé au coma éthylique et à l'accident d'avion, pour revenir en Irlande, mais ce n'est pas vraiment lui qui est mort "That was another Tristram St Lawrence. " (13) Deux fois revenant, sans identité fixe, " a trembling wreck" (22), ou pire encore "some studied automaton copied from some other studied automaton, ad infinitum, with nothing at the centre " (18), un spectre ("Christy Gaffney stood frozen rigid, a man who had seen a ghost ",19), l'une des âmes errantes ("wandering souls, 20), un cadavre ambulant (" death warmed up ", 288), " a hollow man, an empty shell " comme " the fish heads, the crab claws, the lobster shells and all the other gutted creatures» (290) qui jonchent la rive. Y aurait-il une revanche des crustacés?

Hell. Tristram appartient au monde incertain du fantastique ${ }^{8}$, à cette zone où s'estompe la distinction entre le réel et l'imaginaire et même, on l'a vu, la vie et la mort. Hell fait écho à uncanny : à la fois confirmation et aboutissement. À l'hôpital où il a été admis - et où jamais la formule " entre la vie et la mort " n'a été plus juste - il ressasse : "Hell, hell, hell. I couldn't stop saying that word. Still can't" (82) Il donne une explication qui est bien plus qu'une pirouette :

The cleaners found me comatose and called 999, but the phone must have been upside down and 666 dialled in the panic because it was Hell I was dispatched to, and not hospital, make no mistake. (82)

Plus tard, le whiskey aidant, Tristram est " connected to the bowels of Hell. " (299) Le téléphone est un moyen de communiquer avec la Bête', avec l'enfer, avec le démon - Deauville/Devil - actualisation du gothique en même temps que critique des excès de la pseudo-communication. Toutes les chambres d'hôtel sont identiques : "They are all hell ", abîme où sombrent de conserve la psyché malade et l'Irlande condamnée : "You cannot imagine the depth of the hole into which I had dug myself. " (86) De la même façon, les cauchemars plongent le rêveur dans "la caverne d'effroi ${ }^{10}$ ", image gothique par excellence, ici revisitée par les machines de Hickey : "I had extravagant nightmares about subterranean activity - caverns being excavated beneath the castle. The expansion of Hell was under way in these dreams." (159) L'enfer s'étend sous le château, sapant les fondations de l'ordre traditionnel pour instaurer le règne de la Bête. En parcourant avec Hickey les terres d'une ferme qu'ils aimeraient transformer en lotissement, Tristram lève les yeux vers les étoiles - "The heavens, I remember thinking as I gazed up at them " - mais il est sans espoir : "And down here, the hell. " (249) C'est dans le sous-sol du château

7. Écho probable de «L'homme au sable » des Contes d'Hoffmann, où Nathanaël s'éprend de la poupée mécanique Olympia.

8. Voir par exemple Irène Bessière, Le Récit Fantastique, La poétique de l'incertain, Paris, Larousse, 1974.

9. "Que l'homme doué d'esprit calcule le chiffre de la Bête, c'est un chiffre d'homme : son chiffre, c'est 666. " Apocalypse de Saint Jean, 13:18.

10. Gaston Bachelard, La Terre et les Rêveries du Repos, Paris, Corti, 1948, p. 197. 
que Tristram finit par se cacher : "I took myself under the castle, along the winding subterranean passages to the priest hole [...] I clasped my knees and buried my face and I hid, Fergus, I hid." (342) Tristram, en position foetale, cherchant à " fuir le monde du risque redoutable et hostile ${ }^{11}$ ", à échapper aux hommes, mais bien plus encore à celui qui tire les ficelles : "Deauville. He was on the prowl. " (342)

Deauville/Devil est omniprésent sans jamais être visible. Quand il l'appelle, le portable de Tristram affiche "unknown». Tristram se doute bien de quelque chose, dans la mesure où à une question du juge sur la raison de son retour en Irlande il répond; "An Act of God, or maybe the other fella. " (5) Le démon est un être virtuel, bien dans l'air du temps. Pourtant il apparaît, mais sous des avatars pour le moins inattendus. Le premier est Larney qui comme Tristram est un revenant. Vieux serviteur de la famille, il hante - quoi de plus vrai puisqu'il est mort depuis longtemps ${ }^{12}$ - le parc de Hilltop, et pose à Tristram une série d'énigmes. A la dernière d'entre elles concernant la véritable identité de Deauville il donne une réponse claire : "It's deh-ville. Deh-ville, not doh-ville, yes?" (336) Le second est un promeneur que Tristram prend pour " a local historian» (358) Comme Larney qui épelait le véritable nom du mystérieux Deauville - "Dee. Eee. Vee. Eye. $E l »(336)$ - il explique que l'héritier de Hilltop et tous les autres pensaient faire fortune en un clin d'œil : "But that's the problem with setting yourself up as a little god. You invite the other fella in. Don't you?" (359) La boucle est bouclée, "the other fella " a le dernier mot. Tristram, longtemps égaré, ne comprend le véritable enjeu que sur le tard, grâce à Larney : "The castle was droning, the lights were shining, the heavens were spinning, and the hells. I shook my head. The Devil is my sponsor?" (336)

Tocka tocka. Ce bruit pourtant aurait pu le mettre sur la voie, ce bruit curieux qui résonne partout en contrepoint aux propos de Deauville :

I listened to him touch-typing on his keyboard, tocka tocka, tocka tocka. He was seated at his control panel watching his monitors, firing off instructions from his executive chair. That is how I pictured M. Deauville. "

Tocka tocka pour se renseigner sur Hickey : "Tocka tocka on the keyboard as Mr Deauville ran a check" (40) ; "Tocka tocka in the background-what was that strange noise" (85) pour tirer Tristram des griffes de l'alcool; tocka tocka pour lancer l'affaire de Castle Holdings et Tocka tocka, Tocka tocka (99-101) pour approuver l'investissement; Tocka tocka pour l'offre sur Pudong assortie d'un encouragement ironique : «Bona fortuna. » (238)

11. G. Durand, Les Stuctures anthropologiques de l'Imaginaire, Paris, Bordas, 1969, p. 275.

12. Aussi mort que le narrateur anonyme de The Third Policeman de Flann O'Brien, publié en 1967, et que Skippy, le héros du roman de Paul Murray, Skippy dies. 
Tocka tocka du clavier? A coup sûr, puisque l'ordinateur est, avec le téléphone portable, l'instrument moderne du démon, lui-même caché dans le monde virtuel de la finance internationale. Mais autre chose aussi, de bien plus grave : "Tocka tocka, Tocka tocka. Not fingertips flying across a keyboard but the sound of hooves. " (334) Larney/Deauville révèle sa véritable nature à la conscience coupable de Tristram : "Hooves. No matter which way I turned : hooves. " (336) Tantôt géant, tantôt gnome, le démon gratifie Tristram d'une "goatish dance " avant de lui demander de payer son tribut: "Deauville had come to collect. " (360)

C'est ici que le point de vue choisi par Claire Kilroy prend tout son sens. Comme point de départ elle avait pensé à Hickey, mais celui-ci lui avait paru vite privé d'étoffe : d'où l'idée de choisir Howth Castle - "that's a whole way of life, that's something that's been here over 900 years " - et Tristram : "[...] it had to be someone who had a huge heritage to lose." De plus le choix d'une voix est primordiale (celle de Hickey étant "bawdy ") : "I needed a voice that could reflect on its own actions: the boom was orchestrated by people that don't think ${ }^{13}$. "Le schéma narratif sur lequel fonctionnent nombre de romans de la tradition gothique est bien en place : une big house, un héritier longtemps errant revenu au pays natal, un démon dans l'ombre, son agent opérant au grand jour, une chute en enfer.

Tristram se sent coupable de forfaiture, simplement en regardant autour de lui. Le paradis s'efface - "The view my ancestors would have enjoyed was due to be bricked up again, by me " - les panneaux préviennent, interdisent - "Danger. Concealed Exit. Hard Hat Area " - panneaux auxquels, de son cru, Tristram ajoute : "Abandon Hope. " (162) C'est Dante, bien sûr, aux portes de l'Enfer - "Abandon all hope, ye who enter here" - c'est aussi Vathek et Nouronihar au sein des cavernes d'Eblis, à l'énoncé du " décret terrible et irrévocable " : "Their hearts immediately took fire, and they, at once, lost the most precious gift of heaven: - Hope $e^{14}$. "Échos littéraires qui placent le roman dans le contexte plus large de la nekya, structure fondamentale de tous les récits inspirés, de près ou de loin, par celui de la Chute originelle dont ils reprennent le schéma. The Devil I Know se teinte alors d'une sombre coloration, la métaphysique prenant le relais de la satire et se donnant les outils du fantastique pour parvenir à ses fins : "The more black the situation became, the darker and more gothic the novel became ${ }^{15}$." Les clients qui se pressent pour acheter à prix d'or les appartements mis en vente " off the plans» (183) par Hickey sont des "medieval supplicants» (186), et leur folie est le pendant naturel de celle des "Bills» du Cercle d'Or qui, autour de leurs projets, se mue en un "medieval display of mettle. " (237) Danse des fous, danse macabre,

13. Réponse de Claire Kilroy à Derek Flynn, "Conversation with Claire Kilroy », Writings.ie/Interviews, 21 Aug. 2012.

14. William Beckford, Vathek, (1786), London, Oxford University Press, 1970, p. 119.

15. "Conversation ", Ibid. 
dans un nouveau moyen-âge, un nouvel âge de ténèbres qui s'étend aux portes de Hilltop - "There was just the darkness. It was everywhere " - (206) et sur la campagne où se perd la voiture " our vessel was adrift in a sea of black» (249), et où l'esprit s'égare sur les chemins de l'enfer : "The blackness of the surrounding fields facilitated this strain of thought " (253). "Ce noir est l'or du démon ${ }^{16}$ " : ce qui vaut pour les fonds noirs de Goya vaut pour cette obscurité primordiale.

Avec cette variante contemporaine du pacte faustien le livre se clôt par une descente aux enfers que Tristram est obligé d'affronter les yeux ouverts : " $I$ am afraid of what I will see. " (361) La personnification à l'œuvre ici est dans le droit fil de la théologie catholique où le diable, diabolos, est une personne qui se met en travers du chemin pour entrainer l'homme dans son unique projet : faire le mal. Dans The Devil I Know où les événements et les images qui les connotent se déclenchent comme les répons attendus d'un rituel bien rôdé, le fantastique est venu déployer son voile moins pour brouiller les repères que pour faire du texte une fable morale où s'exprime l'indignation de l'auteure. Indignation non feinte qui enferme l'action dans un carcan iconographique médiéval (grotesques, danse macabre, diables aux pieds fourchus, souterrain à la fois refuge et prison), retour aux sources où le mot gothique retrouve sa signification originelle. À travers les interstices du réel s'infiltre le pouvoir du Malin qui ne cesse de travailler le monde où nous vivons. Pour J. C. Chandor, réalisateur de Margin Call (2011), film qui met en scène le krach d'une banque d'affaires en une nuit : "Le succès du capitalisme s'explique par sa capacité à s'adresser à nos instincts reptiliens ${ }^{17}$. "L'Irlande en fournit ici une éclatante démonstration.

D'autres écrivains, dramaturges ou romanciers, dénoncent les méfaits de la cupidité des temps modernes. Donal Ryan se penche sur les abandonnés du boom économique dans un village de l'ouest (The Spinning Heart, 2013) et, Anne Enright stigmatise le matérialisme (The Forgotten Waltz, 2011). The Devil I Know, à la différence des précédents, est une fable morale, une «étude philosophique» qui, comme celles de Balzac, relève au moins en partie du fantastique ${ }^{18}$. Dans une veine analogue on trouve The Seafarer (2006) de Conor McPherson : James "Sharky » Harper joue son âme au poker avec le démoniaque Mr Lockhart qui dépeint un enfer glacé inspiré d'un poème médiéval. Terminus ${ }^{19}$, " a luridly compelling waking nightmare of Dublin as an eighth circle of hell ${ }^{20}$ " met en scène un serial killer misogyne qui a conclu un pacte avec le diable. Animals (2006), de Keith Ridgway est une véritable entreprise de déréalisation opérée par le délire

16. André Malraux, Le Triangle noir, Gallimard, 1970, p. 86.

17. Propos recueillis par A. Tonet dans Le Monde du 31 décembre 2014.

18. On peut songer à La Peau de Chagrin.

19. Pièce de Mark O'Rowe, jouée à l'Abbey Theatre le 9 juin 2007.

20. Brian Logan, The Guardian, 5 April 2011. 
hallucinatoire du héros. Dans un roman étourdissant, Skippy Dies (2010), Paul Murray, entre maintes autres choses, évoque un monde souterrain où le prince des ténèbres manipule les âmes des hommes.

Indignée, alarmée, Claire Kilroy, nous démontre que la crise est un phénomène démoniaque où notre humanité se perd. Fin du passage sur cette terre pour Tristram, fin d'un temps - "I was stricken by an overwhelming sense of things coming to an end " (360) - "waste land "né de la folie humaine, monde que la seule évocation du nom du Malin suffit, littéralement, à pétrifier ${ }^{21}$ :

"Desperate, the devastation they wreaked. It is nothing short of diabolic."

At this word, the birds stopped. The secret creatures in the undergrowth stopped. The very air, I tell you, stopped. (359)

21. Le démon arrête l'épée de Valentin dans le Faust de Goethe. Après avoir tué le frère d'Isidora, Melmoth n'a qu'un geste à faire pour arrêter ceux qui se précipitent sur lui : "Every arm is paralyzed - every mind is frozen to its centre! », C.R Maturin, Melmoth the Wanderer, (1820), A Bison Book, Lincoln, University of Nebraska Press, 1963, p. 97. 